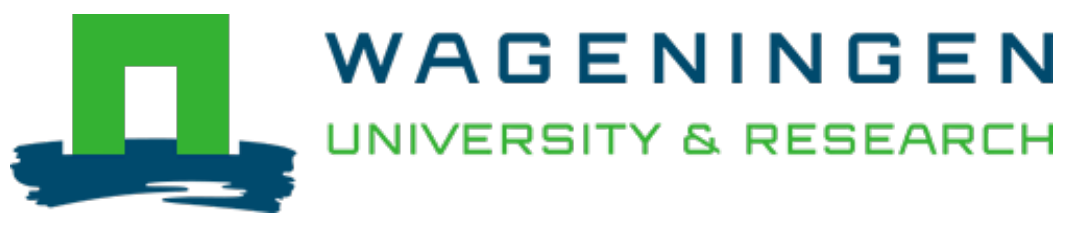

\title{
Acceleration of the fermentation of kenkey, an indigenous fermented maize food of Ghana.
}

\author{
Food Research International \\ Nout, M.J.R.; Kok, B.; Vela, E.; Nche, P.F.; Rombouts, F.M. \\ https://doi.org/10.1016/0963-9969(95)00059-3
}

This publication is made publicly available in the institutional repository of Wageningen University and Research, under the terms of article $25 \mathrm{fa}$ of the Dutch Copyright Act, also known as the Amendment Taverne. This has been done with explicit consent by the author.

Article 25 fa states that the author of a short scientific work funded either wholly or partially by Dutch public funds is entitled to make that work publicly available for no consideration following a reasonable period of time after the work was first published, provided that clear reference is made to the source of the first publication of the work.

This publication is distributed under The Association of Universities in the Netherlands (VSNU) 'Article $25 \mathrm{fa}$ implementation' project. In this project research outputs of researchers employed by Dutch Universities that comply with the legal requirements of Article $25 \mathrm{fa}$ of the Dutch Copyright Act are distributed online and free of cost or other barriers in institutional repositories. Research outputs are distributed six months after their first online publication in the original published version and with proper attribution to the source of the original publication.

You are permitted to download and use the publication for personal purposes. All rights remain with the author(s) and / or copyright owner(s) of this work. Any use of the publication or parts of it other than authorised under article $25 \mathrm{fa}$ of the Dutch Copyright act is prohibited. Wageningen University \& Research and the author(s) of this publication shall not be held responsible or liable for any damages resulting from your (re)use of this publication.

For questions regarding the public availability of this publication please contact openscience.library@wur.nl 


\title{
Acceleration of the fermentation of kenkey, an indigenous fermented maize food of Ghana
}

\author{
M. J. R. Nout, ${ }^{a *}$ B. Kok, ${ }^{a}$ E. Vela, ${ }^{a}$ P. F. Nche $^{b}$ \& F. M. Rombouts ${ }^{a}$ \\ ${ }^{a}$ Department of Food Science, Agricultural University, Bomenweg 2, 6703 HD Wageningen, The Netherlands \\ ${ }^{b}$ Present address: Food Science Research Unit, University of Natal, King George V Avenue, Durban 4001, South Africa
}

\begin{abstract}
Kenkey is a popular staple food of Ghana. It consists of fermented and cooked maize dough, wrapped in leaves. The traditional kenkey-making process is laborious and time consuming (4-6 days). An accelerated option for industrial manufacture of kenkey in sausage casings was devcloped, which takes approximately $24 \mathrm{~h}$. Hydration of maize to $40 \%$ (w/w) moisture content was shortened from 48 to $10 \mathrm{~h}$ by pre-cracking the kernels. Fermentation was shortened from 3-4 days to $12 \mathrm{~h}$ by incorporating the aflata into the dumpling prior to fermentation, and by using a starter dough. Cooking time and thus energy expenditure was reduced from $2 \mathrm{~h}$ to $35 \mathrm{~min}$ by changing the dimensions of the kenkey mass from $10-15 \mathrm{~cm}$ diameter balls to $6 \mathrm{~cm}$ diameter cylinders. Due to the different conditions, yeasts were somewhat more active than in traditional kenkey, resulting in higher ethanol levels. However, these remained low and ethanol had disappeared after cooking. The combination of lactic acid fermentation and cooking resulted in a microbiologically stable product, even after the dumpling had been deliberately contaminated. Copyright (C) 1996 Canadian Institute of Food Science and Technology. Published by Elsevier Science Ltd.
\end{abstract}

Keywords: fermented, cereal, maize, Ghana, Africa.

\section{INTRODUCTION}

Kenkey, a popular Ghanaian staple food is produced from fermented maize dough. During kenkey production (Muller \& Nyarko-Mensah, 1972; Nche et al., 1994a) part of the fermented maize dough (usually half) is slurried with water and cooked to gelatinization to give a thick and sticky paste, called the aflata (Figure 1). The aflata serves as a binding agent and moisturizer when it is subsequently mixed with the uncooked remainder of the dough (Nche et al., 1996). When kneaded, the aflata holds the uncooked dough together in a dumpling which can then be shaped, wrapped and boiled to give kenkey.

The traditional process is carried out at an artisanal level. It takes considerable time (4-6 days), physical labour (aflata making, kneading and wrapping of dumplings) and energy (two cooking stages). In view of

\footnotetext{
*To whom correspondence should be addressed.
}

facilitating convenience in an era characterized by increasing urban populations, it is realistic to assess options for industrial-scale manufacture of kenkey.

It was shown that some parts of the kenkey process can be upgraded by shortening the fermentation period using an accelerated fermentation process (Nche et al., 1994b) or by reducing physical labour using pre-cooked dehydrated kenkey mixes (Nche et al., 1996).

The present paper deals with an alternative approach to the kenkey-making process. The general principle is shown in Figure 2. The major difference compared with the traditional process is that the fermentation takes place after the dumpling has been made and filled into a casing material, instead of fermentation prior to dumpling making. In addition, several stages have been optimized (i.e. soaking period, amount of aflata used, fermentation period and cooking time). This would finally result in a $24 \mathrm{~h}$ process with reduced energy requirement, yielding a ready-to-eat product. 


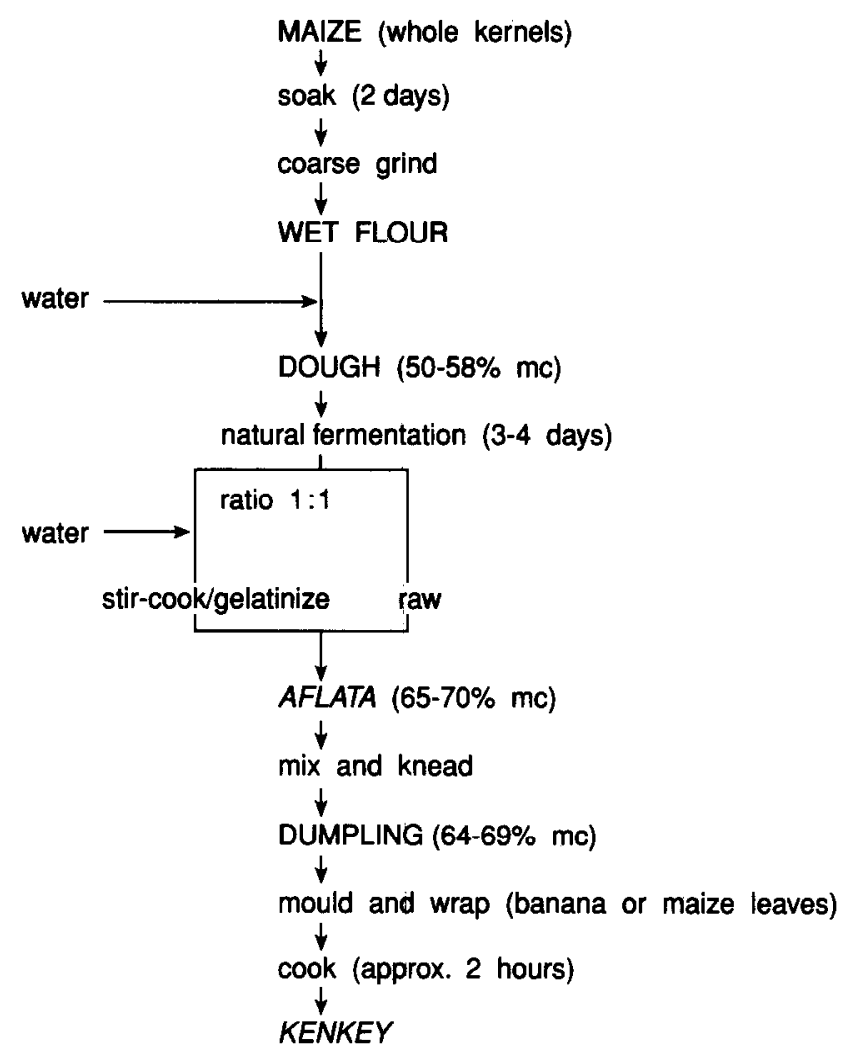

Fig. 1. Traditional kenkey manufacturing process.

\section{MATERIALS AND METHODS}

\section{Materials}

White dent maize (Zea mays L.) grown in Zimbabwe was used. For the sausage casing, Nalo Faser I cellulose fibre casing ( $6 \mathrm{~cm}$ diameter) was supplied by Foodpack, Harderwijk, The Netherlands.

\section{Methods}

A steel roller mill (Turner, Ipswich, UK) with a $3 \mathrm{~mm}$ gap was used to crack the maize. For grinding, a hammer mill (Fritsch Pulverisette type 14.702, Marius Instruments, Utrecht, The Netherlands) with fine rotor and $4 \mathrm{~mm}$ sieve (coarse grinding) or $2 \mathrm{~mm}$ sieve (fine grinding) was used at Speed 2.

\section{Microbiological}

Maize dough ( $100 \mathrm{~g}$ maize flour $+40.5 \mathrm{ml}$ water) was inoculated with $10 \%(\mathrm{w} / \mathrm{w})$ of previously fermented dough, and incubated for $24 \mathrm{~h}$ at $30^{\circ} \mathrm{C}$. The resulting starter dough was used as en inoculum at $10 \%(\mathrm{w} / \mathrm{w})$ level (Nche et al., 1994a).

In the microbiological analyses, lactic acid bacteria were enumerated in MRS (deMan, Rogosa and Sharpe) agar with addition of $1 \mathrm{~g} / 1$ natamycin, yeasts were enumerated in oxytetracycline-yeast extract glucose

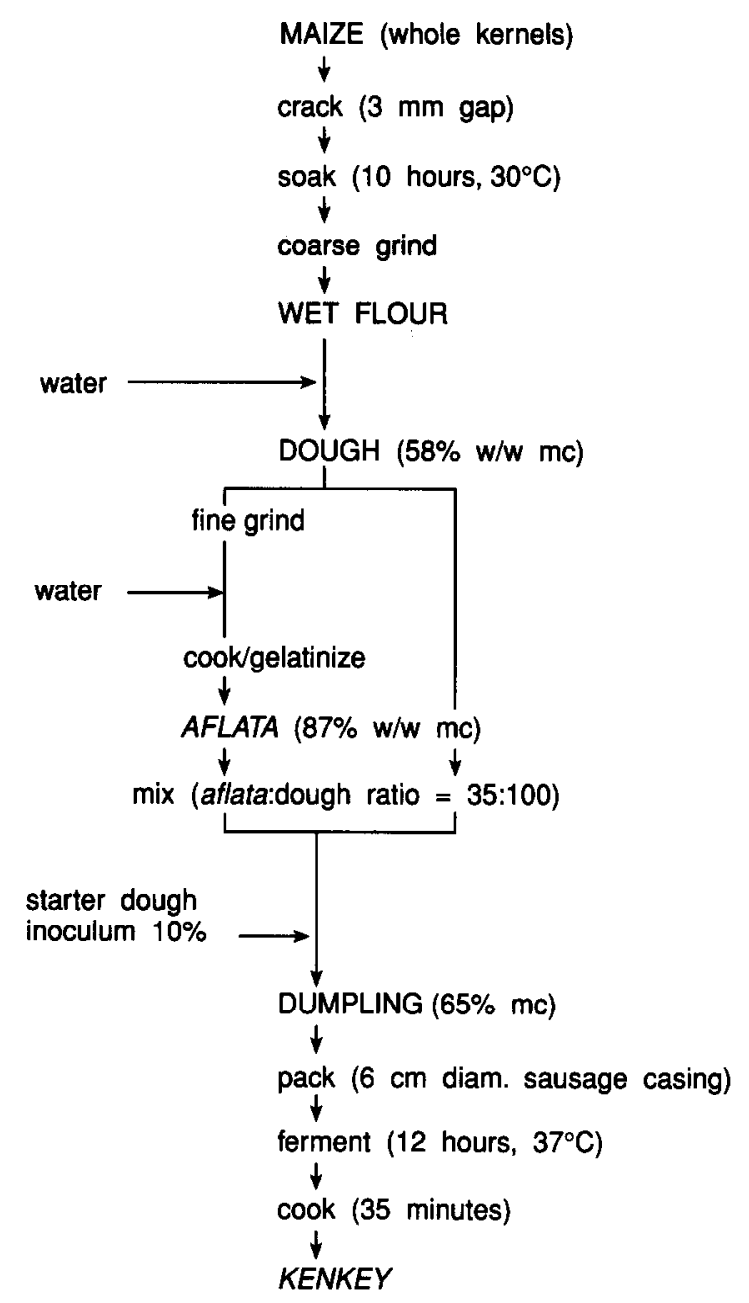

Fig. 2. Accelerated kenkey process in sausage casings.

agar and enterobacteriaceae were enumerated in Violet Red Bile Glucose agar as described by Nout et al. (1987). All growth media were obtained from Oxoid, UK. Duplicate samples were made into serial dilution series; appropriate dilutions were plated on duplicate counting plates.

For the contamination experiment, Escherichia coli (strain LMM 085) was grown in Brain Heart Infusion Broth overnight at $37^{\circ} \mathrm{C}$. Soil suspension was obtained by suspending $1 \%(\mathrm{w} / \mathrm{v})$ garden soil in tapwater, followed by filtration through filter paper. For challenge testing, kenkey dumpling was contaminated with $1 \%$ (v/w) E. coli culture and $1 \%(\mathrm{v} / \mathrm{w})$ soil suspension.

\section{Chemical}

Reducing sugars were determined according to NelsonSomogyi (Kormelink et al., 1991) and related to a glucose calibration curve, measured at $520 \mathrm{~nm}$. Duplicate analyses were made of replicate samples.

The $\mathrm{pH}$ and TA [titratable acidity, expressed as percentage $(w / w)$ lactic acid] were determined (single measurements in replicate samples) according to Nout et al. (1987). 
Table 1. Effect of dough/aflata ratio and of moisture contents of dough on handling and moisture content of dumpling and quality of final kenkey. Traditionally made aflata with $69 \% \mathrm{w} / \mathrm{w}$ moisture content was used (two replicate samples; moisture content analyzed in duplicate)

\begin{tabular}{|c|c|c|c|c|}
\hline \multirow[t]{2}{*}{ Dough/aflata ratio } & \multicolumn{4}{|c|}{ Dough moisture content percentage $(w / w)$} \\
\hline & 40 & 50 & 60 & 70 \\
\hline \multicolumn{5}{|l|}{$1: 0$} \\
\hline Handling of dumpling & Dry & Good & Wet & Wet \\
\hline Moisture content $\%(w / w)$ of dumpling & 49.0 & 57.2 & 59.2 & 68.7 \\
\hline Quality of final cooked kenkey & Dry & Dry & Dry & Wet \\
\hline \multicolumn{5}{|l|}{$3: 1$} \\
\hline Handling of dumpling & Dry & Fair & Good & Wet \\
\hline Moisture content $\%(w / w)$ of dumpling & 39.0 & 60.2 & 63.4 & 71.2 \\
\hline Quality of final cooked kenkey & Dry & Fair & Fair & Wet \\
\hline \multicolumn{5}{|l|}{$2: 1$} \\
\hline Handling of dumpling & & Fair & Good & Wet \\
\hline Moisture content $\%(w / w)$ of dumpling & & 60.9 & 64.4 & 67.5 \\
\hline Quality of final cooked kenkey & & Fair & Fair & Wet \\
\hline \multicolumn{5}{|l|}{$1: 1$} \\
\hline Handling of dumpling & Dry & Sticky & Fair & \\
\hline Moisture content $\%(w / w)$ of dumpling & 55.2 & 64.2 & 65.3 & \\
\hline Quality of final cooked kenkey & Dry & Good & Good & \\
\hline \multicolumn{5}{|l|}{$1: 2$} \\
\hline Handling of dumpling & Dry & Sticky & Fair & \\
\hline Moisture content $\%(w / w)$ of dumpling & 60.8 & 63.9 & 68.7 & \\
\hline Quality of final cooked kenkey & Fair & Good & Good & \\
\hline
\end{tabular}

Lactic acid, acetic acid and ethanol were assayed by high performance liquid chromatography (duplicate analyses in replicate samples) as described previously (De Reu et al., 1995), with butyric acid as an internal standard.

\section{Experimental dumplings}

The following compositions were tested (two replicate samples): $M$ (maize dough with $58 \%$ moisture content), $\mathrm{M}+\mathrm{A}(100 \mathrm{~g} \mathrm{M}+35 \mathrm{~g}$ aflata with $87 \%$ moisture content $), M+I(100 \mathrm{~g} \mathrm{M}+10 \mathrm{~g}$ starter dough), $\mathrm{M}+$ $A+I(M+A+13 g$ starter dough $)$.

\section{Statistical analysis}

Reported data represent mathematical mean values of four data points. Where applicable, statistical significance was assessed using Student's $t$-tests (Snedecor \& Cochran, 1980).

\section{RESULTS AND DISCUSSION}

A time saving of $38 \mathrm{~h}$ could be achieved during the soaking stage. When soaked in water at $30^{\circ} \mathrm{C}$, whole kernels slowly reached a maximum moisture content of $40 \%(w / w)$ after $48 \mathrm{~h}$. On the contrary, maize cracked in a $3 \mathrm{~mm}$ gap crushing mill took only $10 \mathrm{~h}$ to stabilize at its maximum moisture level of $40-42 \%(w / w)$.
Uncooked coarsely ground maize flour absorbed water to a maximum of $58.0 \%(\mathrm{w} / \mathrm{w})$. Attempts to produce kenkey without incorporating aflata were unsuccessful on two accounts: (a) the dough lost its shape without being held together by the cementing effect of aflata; (b) after cooking, the centre was hard and dry. This indicates the two-fold function of aflata as dough binder and supplier of additional moisture. In a bid to reduce energy expenditure associated with aflata making, the quantity of aflata was minimized. Table 1 shows the effect of different dough/aflata ratios, and dough moisture contents, on dumpling handling and properties of the final cooked kenkey. This experiment was carried out with an aflata of $69 \%(\mathrm{w} / \mathrm{w})$ moisture content made according to the traditional Ghanaian method.

The optimum moisture content of the dumpling was about $65 \%$. At this moisture content, a proper final product was obtained after cooking. When dough of 50 or $60 \%$ moisture content was used in a ratio of $1: 1$ or 1:2 with aflata, a proper final product was obtained. As dough of $50 \%$ moisture with these ratios of aflata resulted in a sticky dumpling, it is advantageous to use doughs of approx. $60 \% \mathrm{mc}$. In the traditional process, half of the weight of maize needs to be turned into aflata to achieve a final moisture content of $65 \%$. However, we found that maize can absorb considerably more water in aflata after a fine grind. Exploiting the 


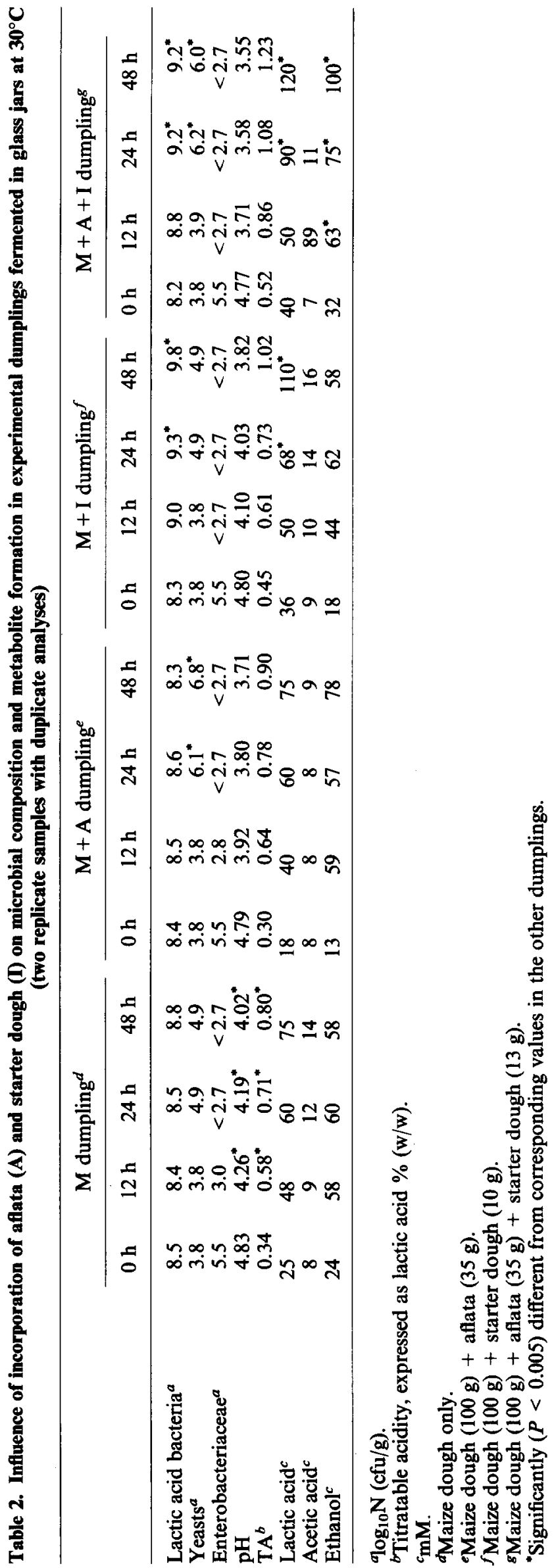




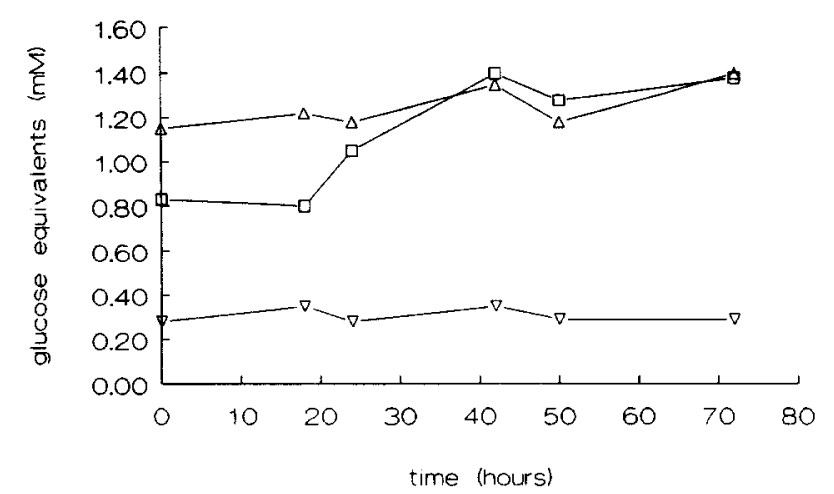

Fig. 3. Effect of aflata and starter dough addition on the evolution of reducing sugars at $4^{\circ} \mathrm{C}$ in maize dumpling. $\triangle M$ $+\mathrm{A}+1$ dumpling (100 $\mathrm{g}$ maize dough $+35 \mathrm{~g}$ aflata $+13 \mathrm{~g}$ starter dough); $\square \mathbf{M}+$ A dumpling (100 g maize dough + $35 \mathrm{~g}$ aflata); $\nabla \mathrm{M}$ dumpling (maize dough only). (Two replicate samples with duplicate analyses.)

maximum water absorption capacities of both dough $(58 \% \mathrm{w} / \mathrm{w})$ and aflata $(87 \% \mathrm{w} / \mathrm{w})$ we obtained excellent results with a ratio of $100 \mathrm{~g}$ dough to $35 \mathrm{~g}$ aflata, resulting in a dumpling with $65 \%(\mathrm{w} / \mathrm{w})$ moisture content.

In order to assess the influence of aflata incorporation prior to fermentation on the amount of fermentable carbohydrates, various dumplings were prepared and kept at $4^{\circ} \mathrm{C}$ to minimize microbial metabolism. Figure 3 shows that the addition of aflata as mentioned earlier $(\mathrm{M}+\mathrm{A})$ significantly $(P<0.005)$ increases the level of reducing sugars (expressed as glucose equivalents) compared with maize dough (M) alone. The reducing sugars are released from the gelatinized starch of the aflata, by the endogenous amylases in the uncooked maize dough. Addition of starter dough $(\mathbf{M}+\mathbf{A}+\mathbf{I})$ did not result in a significant additional release of reducing sugars. This indicates that the microorganisms in the starter dough do not have amylolytic activities of importance.
Fermentation of experimental dumplings was carried out in sterile glass jars to evaluate the effect of aflata and starter dough on microbial development, acidity and metabolite formation (Table 2). Within a $48 \mathrm{~h}$ fermentation period, the level of lactic acid bacteria was higher in dumplings with starter dough addition, as expected. Nevertheless, the endogenous flora of lactic acid bacteria on non-inoculated maize dough is already quite high. Additions of aflata and starter dough to the dumpling appear to have further effects resulting in significant $(P<0.005)$ acceleration of $\mathrm{pH}$ decrease and higher levels of titratable acidity, as well as lactic acid in the combination $\mathbf{M}+\mathbf{A}+\mathbf{I}$. Yeasts were favoured by the incorporation of aflata but not by starter dough. This resulted in higher levels of ethanol in $\mathbf{M}+\mathbf{A}$ and $\mathrm{M}+\mathrm{A}+\mathrm{I}$. This could be a disadvantage during processing as it would be accompanied by larger volumes of $\mathrm{CO}_{2}$ gas which could accumulate in the sausage casings. In all experimental dumplings, the level of acid-sensitive enterobacteriaceae was reduced to below detection level within $24 \mathrm{~h}$, or within $12 \mathrm{~h}$ when starter dough was used. Acetic acid was present at relatively low levels and it was not significantly affected by experimental conditions.

When dumpling $\mathrm{M}+\mathrm{A}+\mathrm{I}$ was filled into $6 \mathrm{~cm}$ diameter cellulose sausage casings, $15 \mathrm{~min}$ were required to achieve a temperature of $85^{\circ} \mathrm{C}$ at the centre of the sausage, when immersed in boiling water. In order to ensure adequate reduction of vegetative microbial cells, a total cooking time of $35 \mathrm{~min}$ was chosen.

Table 3 summarizes the changes of microbial composition and acidity in dumplings with or without deliberate contamination with an $E$. coli culture after $12 \mathrm{~h}$ fermentation at $37^{\circ} \mathrm{C}$ in $6 \mathrm{~cm}$ diameter casings followed by 35 min cooking in boiling water. The fermentation period of $12 \mathrm{~h}$ was chosen to achieve a $\mathrm{pH}<4.0$. The data show a drastic reduction in naturally occurring, as well as added, enterobacteriaceae. The cooking period was adequate to kill vegetative cells to

Table 3. Microbial composition and acidity of $M+A+I$ dumplings, fermented with and without added contamination at $37^{\circ} \mathrm{C}$, and their respective final products after 35 min cooking (two replicate samples with duplicate analyses)

\begin{tabular}{lcccc}
\hline & Lactic acid bacteria & Yeasts & Enterobacteriaceae & pH \\
\hline Fresh dumpling $^{a}$ & $8.7^{8}$ & 4.2 & 5.7 & $4.78^{*}$ \\
Fermented dumpling $^{b}$ & 8.9 & 4.2 & $3.2^{*}$ & 3.91 \\
Cooked kenkeyc $^{c}$ & $<2.7^{*}$ & $<2.7^{*}$ & $<2.7^{*}$ & 4.01 \\
Contaminated dumpling $^{d}$ & 8.8 & 7.1 & 7.3 & $4.76^{*}$ \\
Fermented dumpling $^{e}$ & 8.9 & 6.0 & $5.5^{*}$ & 3.90 \\
Cooked kenkey $^{*}$ & $<2.7^{*}$ & $<2.7^{*}$ & $<2.7^{*}$ & 4.00 \\
\hline
\end{tabular}

${ }^{a} 100 \mathrm{~g}$ maize dough $(58 \%$ moisture content $)+35 \mathrm{~g}$ aflata $(87 \%$ moisture content $)+13 \mathrm{~g}$ starter dough.

${ }^{b}$ Fermented for $12 \mathrm{~h}$ at $37^{\circ} \mathrm{C}$ filled in $6 \mathrm{~cm}$ cellulose sausage casings.

${ }^{c}$ Cooked by immersion in boiling water bath for $35 \mathrm{~min}$.

${ }^{d}$ Contaminated with $10^{7} / \mathrm{g} E$. coli and $1.0 \%$ (v/w) soil suspension.

${ }^{e}$ Contaminated dumpling fermented as footnote $b$.

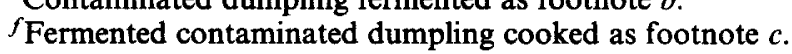

${ }^{g} \log _{10} \mathrm{~N}(\mathrm{cfu} / \mathrm{g})$.

*Significance $(P<0.005)$. 
below plate count detection level. Some endosporeforming bacteria might have remained. However, these would not be able to germinate at the prevailing $\mathrm{pH}$ conditions.

It is concluded that the traditional 4-6 days kenkey manufacturing procedure can be shortened to $24 \mathrm{~h}$ by a combination of reducing soaking time of maize, by using a starter dough in a dough-aflata mixture, and by cooking in sausage casings. The latter operation would result in considerable savings on cooking time and thus of thermal energy.

\section{ACKNOWLEDGEMENTS}

This work was carried out in the context of an ECsponsored project (Contract No. TS2-0267-UK; The evaluation and improvement of traditional fermented cereals and legumes in Ghana).

\section{REFERENCES}

De Reu, J. C., Rombouts, F. M. \& Nout, M. J. R. (1995). Influence of acidity and initial substrate temperature on germination of Rhizopus oligospores sporangiospores in tempe fermentation. J. Appl. Bacteriol., 78, 200-8.

Kormelink, F. J. M., Van de Vis, J. W., Searle-Van Leeuwen, M. J. F. \& Voragen, A. G. J. (1991). Comparison of different reducing sugar assays in relation to their application to glycanase tests. Food Hydrocolloids, 4, 481-7.

Muller, H. G. \& Nyarko-Mensah, B. (1972). Studies on kenkey, a Ghanaian cereal food. J. Sci. Food Agric., 23, 544 5.

Nche, P. F., Nout, M. J. R. \& Rombouts, F. M. (1994). The effect of cowpea supplementation on the quality of kenkey, a traditional Ghanaian fermented maize food. $J$. Cereal Sci., 19, 191-7.

Nche, P. F., Odamtten, G. T., Nout, M. J. R. \& Rombouts, F. M. (1994). Dry milling and accelerated fermentation of maize for industrial production of kenkey, a Ghanaian cereal food. J. Cereal Sci., 20, 291-8.

Nche, P. F., Odamtten, G. T., Nout, M. J. R. \& Rombouts, F. M. (1996). Soaking determines the quality of aflata for kenkey production. $J$. Cereal $S c i$, in press.

Nout, M. J. R., Beernink, G. \& Bonants-Van Laarhoven, T. M. G. (1987). Growth of Bacillus cereus in soyabean tempeh. Int. J. Food Microbiol., 4, 293-301.

Snedecor, G. W. \& Cochran, W. G. (1980). Statistical Methods, 7th edn. The Iowa State University Press, Ames, Iowa.

(Received 23 May 1995; accepted 10 September 1995) 